\title{
A Systematic Review of Alternative Nicotine Delivery System (ANDS)-Based Interventions on Smoking-Related Health Outcomes Among Marginalised Population Groups.
}

Florian Scheibein ( $\nabla$ fscheibein@gmail.com )

Waterford Institute of Technology https://orcid.org/0000-0001-9585-5068

Martina Gooney

School of Health Sciences, Waterford Institute of Technology

Adrian Jones

NHS Wales

Evan Matthews

School of Health Sciences, Waterford Institute of Technology

Kevin McGirr

University of California, San Francisco

Andy Morrison

New Nicotine Alliance

John SG Wells

School of Health Sciences, Waterford Institute of Technology

\section{Research}

Keywords: Smoking, marginalised group, nicotine replacement therapy, electronic nicotine delivery systems

Posted Date: November 16th, 2021

DOI: https://doi.org/10.21203/rs.3.rs-1048408/v1

License: (9) This work is licensed under a Creative Commons Attribution 4.0 International License. Read Full License 


\section{Abstract}

\section{Background:}

Smoking and smoking-related disease is endemic amongst many marginalised populations such as people experiencing homelessness, people who use drugs, people living with HIV, sex workers and members of the LGBTQ+, Indigenous, Traveller and migrant communities. Alternative Nicotine Delivery Systems (ANDS)-based interventions including those using Nicotine Replacement Therapy (NRT) and Electronic Nicotine Delivery Systems (ENDS) show promise in supporting people to reduce their smoking. However, little is known about ANDS-based smoking reduction interventions with marginalised populations. This systematic review provides a best evidence synthesis of ANDS-based smoking reduction interventions to address this gap.

\section{Methods:}

A systematic review protocol was registered on PROSPERO (CRD42020158832) and literature review conducted through MEDLINE/PubMed, CINAHL, EMBASE, OVID SP, ScienceDirect and Google Scholar. The primary outcomes of cigarette smoking, and biochemical validation of abstinence were reported. Secondary outcomes reported included physical health, mental health and other outcomes.

\section{Results:}

Twenty-Nine studies were included in this review. Thirteen of the included studies were randomised controlled trials (RCTs) $(n=2828)$ and 16 studies were quasi controlled studies $(n=1172)$. The sample size across the studies ranged from 9 to 775 participants. The mean reported age of participants ranged from 32.4 to 56.9 years old with an overall mean age of 39.55. A minority of study participants identified as female (33.43\%; with two studies not reporting gender). A range of ANDS-interventions were found to be effective in reducing smoking amongst a range of marginalised groups. However, the overall quality of both the controlled and quasi experimental studies, as evaluated using the JBI Appraisal Tool, was found to be low.

\section{Conclusions:}

Studies are often evaluated as homogenous interventions although they are frequently a group of interventions and lack power analysis of the effects of individual components of the intervention effect. Several studies suggest potential mental health benefits consequent of ANDS-based intervention, though this effect is poorly explored. There is a current lack of RCTs related to ANDS-based smoking related interventions with people experiencing homelessness. Similarly, there is a lack of properly controlled RCTs exploring the use of ENDS with marginalised populations. Future studies should aim to address these deficits.

\section{Introduction}


Although tobacco smoking has been decreasing in many higher income countries, it remains endemic amongst many marginalised populations in both lower and high income countries. ${ }^{1,2}$ Many of these groups are disproportionately impacted by smoking-related diseases such as Chronic Obstructive Pulmonary Disease (COPD) and lung cancer and smoking can dramatically reduce their quality of life and life expectancy. ${ }^{2}$ However, there are limited reviews of evidence-based smoking reduction interventions outside specific marginalised groups such as people experiencing homelessness ${ }^{3,4} \mathrm{~A}$ wide range of marginalised populations have been associated with high smoking rates including people who use drugs ${ }^{5}$, people living with mental illness ${ }^{5}$ and people involved with the criminal justice system ${ }^{7}$. Such minority populations are often excluded from smoking reduction interventions despite their high levels of smoking and smoking-related disease. ${ }^{8}$ The lack of engagement with these groups may be related to a need to identify effective smoking reduction interventions with these groups. ${ }^{8}$

Alternative nicotine delivery systems (ANDS) including nicotine replacement therapy (for example, gums, lozenges and inhalers) and the provision of electronic nicotine delivery systems (ENDS) show some promise in helping a range of marginalised populations to quit or reduce smoking. ${ }^{2,3}$ The systematic review reported in this paper aimed to provide a comprehensive summary of intervention research that has examined the use of ANDS-based interventions in reducing tobacco smoking and other key outcomes in marginalised populations. Within this review marginalised populations defined were people with experience of homelessness; criminal justice involvement; drug use; severe mental illness; sex work; forced displaced or migrant people; people living with HIV and members of the Indigenous, LGBTQ+ and traveller communities.

The key outcomes of interest in this inquiry were:

(I) Self-reported cigarette consumption;

(II) Biochemically validated cessation

(II) Measures of nicotine dependence

(II) Mental outcomes

(IV) Physical outcomes

(VI) Other outcomes

\section{Methodology}

Our review protocol was registered with PROSPERO (CRD42020158832) and followed the PRISMA guidelines. ${ }^{9}$ We conducted the systematic review to summarise evidence for the use of ANDS interventions among various marginalised population groups which are linked to high smoking rates. We 
defined ANDS as including all nicotine-based interventions including various forms of nicotine replacement therapy (for example, nicotine gum, patches and inhaler), ENDS devices and snus.

Studies which were included were those published in peer-review academic journals in English. This study focused broadly on a range of marginalised populations, which were defined by expert consensus. These included people with lived experience of homelessness; criminal justice involvement; drug use; severe mental illness; sex work; forced displacement or migration; people living with HIV and members of the Indigenous, LGBTQ+ and traveller communities.

\section{Inclusion criteria}

To be included in the review, studies were required to have a (i) primary ANDS intervention either controlled or uncontrolled with pre and post measures, (ii) be subject to peer review publication in an academic publication and (iii) include primarily marginalized population group (s) in the intervention - as per the search strategy described below.

\section{Search methods and strategy}

A systematic search of the literature was conducted to identify all intervention studies where ANDS-based interventions had been implemented with 10 separate marginalised population groups as shown below.

\section{Table 1 Search Terms}

1. homeless OR houseless OR "precariously housed" OR unhoused;

2. prisoner OR imprisoned OR prison;

3. "person who uses drugs" OR PWUD OR "person who injects drugs" OR PWID OR "drug user" OR "substance use disorder" OR "drug dependence";

4. Indigenous OR "Native American" OR Maori OR "First Nations";

5. Roma OR gypsy OR Traveller;

6. "serious mental illness" OR "severe mental illness" OR "severe and persistent mental illness"'” OR "common mental disorder" OR "common mental illness" OR schizophrenia OR psychosis OR psychotic OR "major depression" OR depression OR dysthymia OR bipolar OR anxiety OR "posttraumatic stress disorder";

7. "sex worker" OR prostitute OR "rent boy";

8. "Asylum seeker" OR migrant OR refugee;

9. LGBT OR lesbian OR gay OR bisexual OR transgender OR intersex OR queer

10. "People living with HIV" OR PWLHIV OR "HIV patients".

The primary outcomes of cigarette smoking, and biochemical validation of abstinence were reported. Secondary outcomes included physical, mental and other outcomes. Articles from inception to 2020 were included. Articles were reviewed from MEDLINE/PubMed, CINAHL, EMBASE, OVID SP, ScienceDirect and Google Scholar. 


\section{Study selection process}

Three reviewers worked independently to screen articles for inclusion eligibility using Covidence. Where disagreement occurred, a discussion was held and decisions were put to a third independent author (MG, JSW) for a final decision. The data were extracted using the predetermined outcomes. These outcomes were classified under domain areas to allow for summary data extraction and analysis. The generated domain areas are shown in Table 1 below.

\section{Table 2. Key outcomes codes for reporting}

\begin{tabular}{|ll|}
\hline Outcomes & Examples \\
\hline S1: Self-reported smoking & Number of cigarettes, \\
\hline S2: Reported abstinence & 7 day point abstinence \\
\hline S2: Biochemical validation & CO monitoring \\
\hline S3: Measures of dependence (e.g.) & Fagerstrom scores \\
\hline M1: Mental health & Changes in stress, depression etc. \\
\hline P1: Physical Health & Changes in blood pressure, BMI etc. \\
\hline 01: Adherence & Drop out/follow up \\
\hline O2: Other outcomes & Changes in substance use \\
\hline
\end{tabular}

\section{Quality Appraisal}

Four researchers independently assessed the quality of studies brought forward for inclusion in relation to reducing bias in design, conduct and analysis using predetermined criteria. The Joanna Briggs Institute Critical Appraisal tool for Quasi-Experimental studies and the JBI Critical Appraisal tool for Randomised Controlled Trials was adopted for use in this process. ${ }^{10}$

In analysing the results, a best evidence synthesis was conducted, whereby studies with a control group and studies without control measures were considered separately and data, as per Table 1, were extracted from each study. A meta-analysis of data was precluded given the diverse heterogeneous nature of the studies that were included in the final review.

\section{Results}

\subsection{Study selection}


Following the removal of duplicates, a total of 2463 articles were considered at the title and abstract level. One-hundred-and-seven full texts were reviewed, and 77 were excluded with reasons (see Fig. 1 and Appendix 1), with 29 unique studies meeting the eligibility criteria. Full details of the search results are summarized in Fig. 1. PRISMA Flowchart.

\section{Details of included studies and participant's characteristics}

Thirteen of the included studies were randomised controlled trials (RCTs) $(n=2828)$ and 16 studies were quasi controlled studies ( $n=1172$ ). The sample size across the studies ranged from $9^{36}$ to 775 participants. ${ }^{21}$ The mean age of participants ranged from 32.4 years ${ }^{18}$ to $56.9^{38}$ with an overall mean age of 39.55 years (three studies did not report mean age). A minority of study participants identified as female (33.43\%; with two studies not reporting gender).

Several studies focussed on people with severe mental illness $11,13-14,17,21,30-32,38-39$ and people who use alcohol and other drugs. ${ }^{12,18,20-21,35,37,32}$ Other studies focussed on people experiencing homelessness $^{25,27,28,36}$ those involved with the criminal justice system ${ }^{16,22,34}$ and those living with HIV. ${ }^{16,23-24,26}$ Three studies included indigenous groups ${ }^{19,21,32}$ and LGBTQ+ populations. ${ }^{29}$ One study included individuals with affective disorders; individuals with opioid use disorder and smokers with socioeconomic disadvantage ${ }^{21}$ whilst another study included Aboriginal people; people with serious mental illness and people who use drugs ${ }^{32}$. No studies evaluating interventions engaging with members of the Traveller community, sex worker or migrants were identified. Details regarding the included studies are summarized in Tables 1 (controlled trials) and 2 (uncontrolled trials).

\section{Table 1 Controlled Studies}




\begin{tabular}{|c|c|c|c|c|c|}
\hline $\begin{array}{l}\text { Study } \\
\text { authors, } \\
\text { Year }\end{array}$ & $\begin{array}{l}\text { Design, } \\
\text { region, setting }\end{array}$ & Population & Intervention & Control group & $\begin{array}{l}\text { Follow } \\
\text { up }\end{array}$ \\
\hline \multirow[t]{3}{*}{$\begin{array}{l}\text { Allen et al. } \\
(2011)^{11}\end{array}$} & \multirow[t]{3}{*}{$\begin{array}{l}\text { RCT, } \\
\text { Switzerland, } \\
\text { psychiatric } \\
\text { emergency } \\
\text { service }\end{array}$} & $\begin{array}{l}\text { People with } \\
\text { serious mental } \\
\text { illness- } \\
\text { schizophrenia } \\
(n=40) ;\end{array}$ & \multirow[t]{3}{*}{$\begin{array}{l}21 \mathrm{mg} \\
\text { transdermal } \\
\text { nicotine patch }\end{array}$} & \multirow[t]{3}{*}{ placebo patch } & \multirow[t]{3}{*}{$\begin{array}{l}24 \\
\text { hours }\end{array}$} \\
\hline & & $\begin{array}{l}\text { Gender: \% } \\
\text { female } \\
\text { (unknown); }\end{array}$ & & & \\
\hline & & $\begin{array}{l}\text { Age: Mean } \\
\text { (unknown) } \\
\text { range (18-65 } \\
\text { years). }\end{array}$ & & & \\
\hline \multirow[t]{3}{*}{$\begin{array}{l}\text { Carmody et } \\
\text { al. }(2012)^{12}\end{array}$} & \multirow[t]{3}{*}{$\begin{array}{l}\text { RCT, hospital- } \\
\text { based } \\
\text { substance use } \\
\text { program, } \\
\text { United States }\end{array}$} & $\begin{array}{l}\text { People } \\
\text { dependent on } \\
\text { alcohol } \\
(n=162)\end{array}$ & \multirow[t]{3}{*}{$\begin{array}{l}16 \text { sessions of } \\
\text { CBT+ NRT over } \\
36 \text { weeks }\end{array}$} & \multirow{3}{*}{$\begin{array}{l}\text { Usual care: } \\
\text { Smoking } \\
\text { cessation } \\
\text { counselling and } \\
\text { guideline- } \\
\text { concordant } \\
\text { medications }\end{array}$} & \multirow[t]{3}{*}{$\begin{array}{l}52 \\
\text { weeks }\end{array}$} \\
\hline & & $3.18 \%$ female; & & & \\
\hline & & $\begin{array}{l}\text { Age: median } \\
\text { age (50), age } \\
\text { range } \\
\text { (unknown). }\end{array}$ & & & \\
\hline \multirow[t]{3}{*}{$\begin{array}{l}\text { Chan et al., } \\
2020^{13}\end{array}$} & \multirow{3}{*}{$\begin{array}{l}\text { Cluster } \\
\text { randomised } \\
\text { parallel study, } \\
\text { psychiatric } \\
\text { inpatient, } \\
\text { Taiwan }\end{array}$} & $\begin{array}{l}\text { People with } \\
\text { mental illness } \\
(n=310)\end{array}$ & \multirow[t]{3}{*}{$\begin{array}{l}\text { Inhalers, } \\
\text { nicotine gum, } \\
\text { and nicotine } \\
\text { patches }\end{array}$} & \multirow[t]{3}{*}{$\mathrm{N} / \mathrm{A}$} & \multirow[t]{3}{*}{8 weeks } \\
\hline & & $\begin{array}{l}\text { Gender: } 10.9 \% \\
\text { female; }\end{array}$ & & & \\
\hline & & $\begin{array}{l}\text { Age: } 36.92 \pm \\
8.1 .\end{array}$ & & & \\
\hline \multirow[t]{3}{*}{$\begin{array}{l}\text { Christiansen } \\
\text { et al } \\
(2018)^{14}\end{array}$} & \multirow[t]{3}{*}{$\begin{array}{l}\text { RCT, } \\
\text { outpatient } \\
\text { care program, } \\
\text { United States }\end{array}$} & $\begin{array}{l}\text { People with } \\
\text { serious mental } \\
\text { health } \\
\text { issues ( } n=222 \text { ); }\end{array}$ & \multirow{3}{*}{$\begin{array}{l}\text { Four weekly } \\
\text { sessions; } \\
\text { motivational } \\
\text { component; pre- } \\
\text { quit nicotine } \\
\text { patch }(21 \mathrm{mg})\end{array}$} & \multirow[t]{3}{*}{$\begin{array}{l}\text { Attention control } \\
\text { group }\end{array}$} & \multirow[t]{3}{*}{$\begin{array}{l}3 \\
\text { months }\end{array}$} \\
\hline & & $\begin{array}{l}\text { Gender ( } 49 \% \\
\text { female); }\end{array}$ & & & \\
\hline & & Age $(43.8 \pm 9.9$ & & & \\
\hline $\begin{array}{l}\text { Cropsey } \\
(2008)^{15}\end{array}$ & $\begin{array}{l}\text { RCT, state } \\
\text { prison, United } \\
\text { States }\end{array}$ & $\begin{array}{l}\text { Women in a } \\
\text { state prison } \\
\text { (treatment: }\end{array}$ & $\begin{array}{l}\text { 10-week group } \\
\text { intervention } \\
\text { with NRT } \\
\text { (patches }\end{array}$ & No intervention & $\begin{array}{l}12 \\
\text { month } \\
\text { follow } \\
\text { up }\end{array}$ \\
\hline
\end{tabular}




\begin{tabular}{|c|c|c|c|c|c|}
\hline & & $\begin{array}{l}\mathrm{n}=250 \text {; control: } \\
\mathrm{n}=289)\end{array}$ & $\begin{array}{l}\text { according to } \\
\text { manufacturer } \\
\text { instructions) }\end{array}$ & & \\
\hline & & $\begin{array}{l}\text { Gender ( } 100 \% \\
\text { female); }\end{array}$ & & & \\
\hline & & Age $(33.8 \pm 9)$ & & & \\
\hline $\begin{array}{l}\text { Cropsey et } \\
\text { al., }(2014)^{16}\end{array}$ & $\begin{array}{l}\text { Randomised } \\
\text { pilot study, }\end{array}$ & $\begin{array}{l}\text { People living } \\
\text { with HIV }(n=40)\end{array}$ & $\begin{array}{l}\text { 8-weeks of } \\
\text { combination }\end{array}$ & Usual Care & 8 weeks \\
\hline & United States & $\begin{array}{l}\text { Gender: } 42.5 \% \\
\text { female; }\end{array}$ & & & \\
\hline & & $\begin{array}{l}\text { Age: } 44.5 \pm S D= \\
9.9 .\end{array}$ & $\begin{array}{l}\text { with brief } \\
\text { counselling } \\
\text { (SBIRT } \\
\text { framework) }\end{array}$ & & \\
\hline $\begin{array}{l}\text { Dennis et } \\
\text { al., }(2016)^{17}\end{array}$ & $\begin{array}{l}\text { RCT, } \\
\text { outpatient } \\
\text { hospital, } \\
\text { United States }\end{array}$ & $\begin{array}{l}\text { People with } \\
\text { serious mental } \\
\text { illness- Post } \\
\text { Traumatic } \\
\text { Stress Disorder } \\
(n=63)\end{array}$ & $\begin{array}{l}\text { Nicotine patch } \\
\text { pre-loading }\end{array}$ & Placebo patch & $\begin{array}{l}6 \\
\text { month }\end{array}$ \\
\hline & & $\begin{array}{l}\text { Gender: (55\% } \\
\text { female) }\end{array}$ & & & \\
\hline & & Age: $42.3 \pm 10.7$ & & & \\
\hline $\begin{array}{l}\text { Felicione et } \\
\text { al }(2018)^{18}\end{array}$ & $\begin{array}{l}\text { RCT, } \\
\text { outpatient }\end{array}$ & $\begin{array}{l}\text { People who use } \\
\text { drugs }(n=25)\end{array}$ & ENDS device & Placebo liquid & $\begin{array}{l}4 \\
\text { weeks }\end{array}$ \\
\hline & States & $\begin{array}{l}\text { Gender: } 72 \% \\
\text { female; }\end{array}$ & & & \\
\hline & & Age: $32.4 \pm 8.7$ & & & \\
\hline $\begin{array}{l}\text { Gould et al. } \\
(2019)^{19}\end{array}$ & $\begin{array}{l}\text { RCT, } \\
\text { Aboriginal } \\
\text { medical } \\
\text { services, } \\
\text { Australia }\end{array}$ & $\begin{array}{l}\text { Pregnant } \\
\text { Australian } \\
\text { indigenous } \\
\text { women }(n=22)\end{array}$ & $\begin{array}{l}\text { Education } \\
\text { resource } \\
\text { package } \\
\text { (including } \\
\text { webinars; } 3 \\
\text { hour one } \\
\text { sessions); oral } \\
\text { forms of NRT; } \\
\text { CO monitoring }\end{array}$ & $\begin{array}{l}\text { Stepwedge } \\
\text { design }\end{array}$ & $\begin{array}{l}6 \\
\text { months }\end{array}$ \\
\hline & & Age: 16+ & & & \\
\hline $\begin{array}{l}\text { Hall et al. } \\
(2018)^{20}\end{array}$ & $\begin{array}{l}\text { RCT, } \\
\text { buprenorphine }\end{array}$ & $\begin{array}{l}\text { People who use } \\
\text { drugs ( } n=175)\end{array}$ & $\begin{array}{l}\text { Computerised } \\
\text { motivational } \\
\text { feedback; }\end{array}$ & $\begin{array}{l}\text { Brochures on } \\
\text { quitting; self-help } \\
\text { techniques; }\end{array}$ & $\begin{array}{l}18 \\
\text { months }\end{array}$ \\
\hline
\end{tabular}




\begin{tabular}{|c|c|c|c|c|c|}
\hline & $\begin{array}{l}\text { clinic, United } \\
\text { States }\end{array}$ & 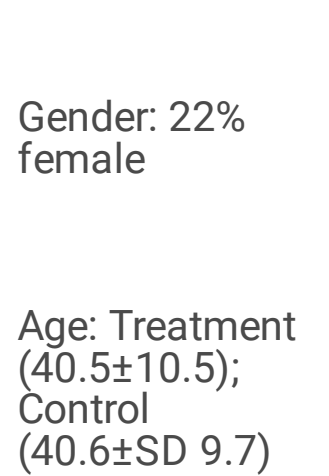 & $\begin{array}{l}\text { nicotine gum } \\
\text { lozenge; } \\
\text { nicotine patch; } \\
\text { optional } \\
\text { varenicline for } \\
\text { those who } \\
\text { failed to } \\
\text { achieve } 24 \text { hour } \\
\text { abstinence }\end{array}$ & $\begin{array}{l}\text { helplines; } \\
\text { smoking } \\
\text { cessation } \\
\text { controls }\end{array}$ & \\
\hline \multirow[t]{3}{*}{$\begin{array}{l}\text { Higgins et } \\
\text { al., }(2020)^{21}\end{array}$} & \multirow[t]{3}{*}{$\begin{array}{l}3 \text { RCTs, } \\
\text { University } \\
\text { Setting, United } \\
\text { States }\end{array}$} & $\begin{array}{l}\text { Individuals with } \\
\text { affective } \\
\text { disorders; } \\
\text { individuals with } \\
\text { opioid use } \\
\text { disorder and } \\
\text { women } \\
\text { smokers with } \\
\text { socioeconomic } \\
\text { disadvantage } \\
\text { (n=775) }\end{array}$ & \multirow[t]{3}{*}{$\begin{array}{l}12 \text { week } \\
\text { intervention } \\
\text { with free } \\
\text { cigarettes } \\
\text { provided with } \\
\text { three } \\
\text { concentration } \\
\text { of nicotine } 0.4 \text {, } \\
2.4 \text {, or } 15.8 \mathrm{mg}\end{array}$} & \multirow[t]{3}{*}{$\mathrm{N} / \mathrm{A}$} & \multirow[t]{3}{*}{$\begin{array}{l}16 \\
\text { weeks }\end{array}$} \\
\hline & & $\begin{array}{l}\text { Gender: 71.1, } \\
\text { female; }\end{array}$ & & & \\
\hline & & $\begin{array}{l}\text { Age: } 35.59 \\
(11.05)\end{array}$ & & & \\
\hline \multirow[t]{2}{*}{$\begin{array}{l}\text { Jalali et al., } \\
(2015)^{22}\end{array}$} & \multirow[t]{2}{*}{$\begin{array}{l}\text { RCT, prison, } \\
\text { Iran }\end{array}$} & $\begin{array}{l}\text { People involved } \\
\text { with criminal } \\
\text { justice } \\
\text { system }(n=43)\end{array}$ & $\begin{array}{l}\text { MI-based } \\
\text { treatment, MI } \\
\text { with NRT, and } \\
\text { the control } \\
\text { group, }\end{array}$ & \multirow[t]{2}{*}{$\begin{array}{l}\text { No intervention } \\
\text { MI }\end{array}$} & \multirow[t]{2}{*}{90 days } \\
\hline & & $\begin{array}{l}\text { Age: } 37.59 \pm \\
8.76\end{array}$ & $\begin{array}{l}\text { Motivation } \\
\text { interview }+2 \mathrm{mg} \\
\text { gum for every } \\
\text { cigarette } \\
\text { smoked/ over } 5 \\
\text { weeks }\end{array}$ & & \\
\hline $\begin{array}{l}\text { Stanton et } \\
\text { al., }(2009)^{23}\end{array}$ & $\begin{array}{l}\text { RCT, } \\
\text { outpatient } \\
\text { clinic, United } \\
\text { States }\end{array}$ & $\begin{array}{l}\text { People living } \\
\text { with HIV ( } \mathrm{n}= \\
412)\end{array}$ & $\begin{array}{l}\text { Bi weekly } \\
\text { sessions where } \\
\text { patch used was } \\
\text { discussed }\end{array}$ & $\begin{array}{l}\text { two study } \\
\text { sessions, } \\
\text { consisting } \\
\text { largely of } \\
\text { baseline } \\
\text { assessments, } \\
\text { randomization, } \\
\text { and brief } \\
\text { assessment of }\end{array}$ & $\begin{array}{l}6 \\
\text { months }\end{array}$ \\
\hline
\end{tabular}


quitting plans.

NRT for those

Age:

$42.04 \pm 7.53$

who wanted to quit

Table 2 Uncontrolled studies 


\begin{tabular}{|c|c|c|c|c|}
\hline $\begin{array}{l}\text { Study } \\
\text { authors, } \\
\text { Year }\end{array}$ & $\begin{array}{l}\text { Design, } \\
\text { region, } \\
\text { setting }\end{array}$ & Population & Intervention & $\begin{array}{l}\text { Follow } \\
\text { up }\end{array}$ \\
\hline $\begin{array}{l}\text { Balfour et } \\
\text { al., }(2016)^{24}\end{array}$ & $\begin{array}{l}\text { Pilot study, } \\
\text { HIV } \\
\text { outpatient } \\
\text { clinic, } \\
\text { United } \\
\text { States }\end{array}$ & $\begin{array}{l}\text { People living with HIV } \\
(\mathrm{n}=50) ; \\
\text { Gender: } 12 \% \text { female } \\
\text { Age: } 45.10 \pm 8.68\end{array}$ & $\begin{array}{l}5 \text { session smoking cessation } \\
\text { counselling, NRT Nicotine patch } \\
\text { per following dosage regiment: } \\
\text { participants smoking } \geq 20 \\
\text { cigarettes per day were } \\
\text { prescribed } 21 \mathrm{mg} \text { patches daily } \\
\text { for } 6 \text { weeks, then } 14 \mathrm{mg} / \text { day for } 2 \\
\text { weeks, followed by } 7 \mathrm{mg} / \mathrm{day} \text { for } \\
2 \text { weeks; participants smoking } \\
10-20 \text { cigarettes per day were } \\
\text { prescribed } 14 \mathrm{mg} \text { patches daily } \\
\text { for } 6 \text { weeks, and then } 7 \mathrm{mg} / \text { day } \\
\text { for } 4 \text { weeks }\end{array}$ & $\begin{array}{l}6 \\
\text { months }\end{array}$ \\
\hline $\begin{array}{l}\text { Buckley et } \\
\text { al., (2017) }{ }^{25}\end{array}$ & $\begin{array}{l}\text { Evaluation } \\
\text { study, } \\
\text { homeless } \\
\text { service, } \\
\text { United } \\
\text { States }\end{array}$ & $\begin{array}{l}\text { People experiencing } \\
\text { homelessness } \\
(\mathrm{n}=139) \\
\text { Gender: } 27.3 \% \text {, } \\
\text { female; } \\
\text { Age: } 44.2 \pm 19-74 \text {; }\end{array}$ & $\begin{array}{l}\text { Student run intervention; smoking } \\
\text { cessation education; motivational } \\
\text { interviewing; } 2 \text { weeks supply of } \\
\text { NRT; referral to national quitline. }\end{array}$ & $\begin{array}{l}26 \\
\text { weeks }\end{array}$ \\
\hline $\begin{array}{l}\text { Cioe et al., } \\
(2019)^{26}\end{array}$ & $\begin{array}{l}\text { Pilot study, } \\
\text { outpatient } \\
\text { HIV clinic }\end{array}$ & 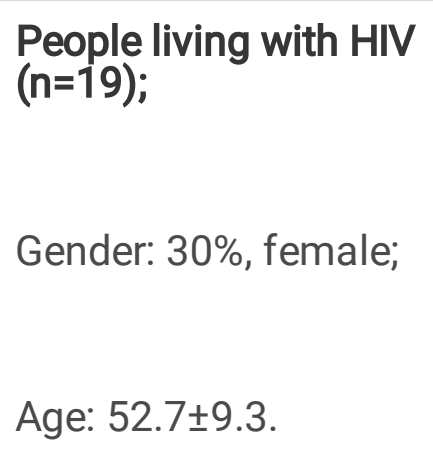 & $\begin{array}{l}8 \text { week intervention; participants } \\
\text { provided with an ENDS device; } \\
\text { weekly allotments of nicotine } \\
\text { liquid; }\end{array}$ & $\begin{array}{l}12 \\
\text { weeks }\end{array}$ \\
\hline $\begin{array}{l}\text { Collins et al., } \\
(2019)^{27}\end{array}$ & $\begin{array}{l}\text { Emergency } \\
\text { homeless } \\
\text { shelter, } \\
\text { United } \\
\text { States }\end{array}$ & $\begin{array}{l}\begin{array}{l}\text { People experiencing } \\
\text { homelessness }(n=44) \text {; }\end{array} \\
\text { Gender: } 34 \% \text { female; } \\
\text { Age: } 48.24 \pm 11.46\end{array}$ & $\begin{array}{l}\text { Information/advice support; } \\
\text { individual sessions; group } \\
\text { sessions; NRT (gum, patches; } \\
\text { lozenges)Choice of ENDS device; } \\
\text { 4mg gum; } 14 \mathrm{mg} \text { and } 21 \mathrm{mg} \\
\text { patch; } 4 \mathrm{mg} \text { lozenges }\end{array}$ & $\begin{array}{l}14 \\
\text { weeks }\end{array}$ \\
\hline $\begin{array}{l}\text { Dawkins } \\
(2020)^{28}\end{array}$ & $\begin{array}{l}\text { Homeless } \\
\text { shelter, } \\
\text { United } \\
\text { Kingdom }\end{array}$ & $\begin{array}{l}\text { People experiencing } \\
\text { homelessness } \\
(n=80)\end{array}$ & $\begin{array}{l}\text { ENDS device, } 4 \text { week supply of } \\
\text { eliquid }\end{array}$ & $\begin{array}{l}24 \\
\text { weeks }\end{array}$ \\
\hline
\end{tabular}


Gender: 35\% female;

Age: $42.66 \pm 10.79$.

\begin{tabular}{|c|c|c|c|c|}
\hline \multirow{3}{*}{$\begin{array}{l}\text { Dickson } \\
\text { Spillman } \\
(2014)^{29}\end{array}$} & \multirow[t]{3}{*}{$\begin{array}{l}\text { Gay health } \\
\text { clinic, } \\
\text { Switzerland }\end{array}$} & $\begin{array}{l}\text { Men who have sex } \\
\text { with men }(n=70) \text {; }\end{array}$ & \multirow[t]{3}{*}{$\begin{array}{l}\text { Seven weekly sessions facilitated } \\
\text { by peers. Multiple different forms } \\
\text { of NRT }\end{array}$} & \multirow[t]{3}{*}{$\begin{array}{l}6 \\
\text { months }\end{array}$} \\
\hline & & Gender: $0 \%$ female; & & \\
\hline & & Age: $42.96 \pm 9.66$ & & \\
\hline $\begin{array}{l}\text { Hickling et } \\
\text { al., } \\
(2019)^{30}\end{array}$ & $\begin{array}{l}\text { Pre/post } \\
\text { feasibility } \\
\text { study, } \\
\text { Community } \\
\text { health } \\
\text { team } \\
\text { referrals, } \\
\text { England }\end{array}$ & $\begin{array}{l}\text { People with serious } \\
\text { mental illness- } \\
\text { psychotic } \\
\text { disorder }(n=50)\end{array}$ & 6 week intervention, ENDS & $\begin{array}{l}24 \\
\text { weeks }\end{array}$ \\
\hline
\end{tabular}

Age: $39 \pm 10.7$

\begin{tabular}{|c|c|c|c|}
\hline $\begin{array}{l}\text { Johnson et } \\
\text { al. }(2020)^{31}\end{array}$ & $\begin{array}{l}\text { Feasibility } \\
\text { study, }\end{array}$ & $\begin{array}{l}\text { People with severe } \\
\text { mental illness }(n=34)\end{array}$ & 2 weeks of NRT (patches) \\
\hline
\end{tabular}

Gender: $47 \%$ female;

Age: $50 \%$ below 40 years old.

Mikhailovich Evaluation Aborginal people; and

Morrison people with serious

$(2008)^{32}$ mental illness months

People who uses drugs

$(n=63)$

Gender: not reported;

Age: not reported .

$\begin{array}{lllll}\text { Pakhale } 33 & \begin{array}{l}\text { A feasibility } \\ \text { mixed } \\ \text { methods } \\ \text { prospective }\end{array} & \begin{array}{l}\text { People who use drugs } \\ (\mathrm{n}=80)\end{array} & \begin{array}{l}6 \text { month intervention; access to } \\ \text { counselling and NRT }\end{array} & \begin{array}{l}6 \\ \text { months }\end{array} \\ & & \end{array}$


cohort Gender: 30\% female;

study,

Community

research

office,

Canada

Richmond et

al $(2006)^{34}$

Pilot study,

prison,

Australia

Age: 43.8 .

People who are

incarcerated $(n=330)$;

Gender: 0\% female;
NRT (patch) $21 \mathrm{mg} /$ day for six weeks, $14 \mathrm{mg} /$ day for two weeks and $7 \mathrm{mg} /$ day for two weeks
6

months

Age: $35 \pm 10$.

\begin{tabular}{|c|c|c|c|c|}
\hline $\begin{array}{l}\text { Saxon, } \\
\text { McGuffin } \\
\text { and Walker, } \\
(1997)^{35}\end{array}$ & $\begin{array}{l}\text { Substance } \\
\text { use } \\
\text { treatment } \\
\text { centre, } \\
\text { United } \\
\text { States }\end{array}$ & $\begin{array}{l}\text { People who use } \\
\text { alcohol and other } \\
\text { drugs }(n=49)\end{array}$ & NRT (patch) 21mg nicotine & $\begin{array}{l}6 \\
\text { weeks }\end{array}$ \\
\hline
\end{tabular}

Gender: $4.1 \%$ female;

Age: $44.1 \pm 7.8$

Scheibein et

al $(2020)^{36}$
Feasibility

study, homeless services, Ireland
People experiencing homelessness $(n=9)$

Gender: 28.57, female;

\section{$43.89 \pm 7.36$.}

\begin{tabular}{|c|c|c|}
\hline $\begin{array}{l}\text { Stein et al } \\
(2016)^{37}\end{array}$ & $\begin{array}{l}\text { Methadone } \\
\text { clinic, } \\
\text { United } \\
\text { States }\end{array}$ & $\begin{array}{l}\text { People who use } \\
\text { drugs- } \\
\text { methadone }(n=12)\end{array}$ \\
\hline
\end{tabular}

Gender: $50 \%$ female

\begin{tabular}{|c|c|}
\hline & Ireland \\
\hline $\begin{array}{l}\text { Stein et al } \\
(2016)^{37}\end{array}$ & $\begin{array}{l}\text { Methadone } \\
\text { clinic, } \\
\text { United } \\
\text { States }\end{array}$ \\
\hline
\end{tabular}

ENDS device; choice of Nicotine

$0,6,11,18$ and $20 \mathrm{mg}$ liquid

3 months
6

ENDS device weeks

Age: $45.9 \pm 11.5$

$\begin{array}{lllll}\text { Valentine } & \begin{array}{l}\text { Veteran } \\ \text { affairs } \\ \text { health } \\ \text { system }\end{array} & \begin{array}{l}\text { Veterans attending } \\ \text { mental health clinics } \\ (\mathrm{n}=43) ;\end{array} & \text { ENDS device } \\ & & \text { Gender: } 7 \% \text { female } & 4 \text { week }\end{array}$

Age: $56.9 \pm 8.0$

White

Recovery
community,

People in alcohol
recovery $(n=100)$;

prolonged

1 year 
$(2016)^{39} \quad$ Iran $\quad$ Gender: $11 \%$, female
nicotine replacement therapy
(NRT) with a broad spectrum of

Age: $40.1 \pm 10.9$

psychosocial supports

\subsection{Controlled trials (CTs)}

\subsubsection{Summary of controlled trials}

The results from the included CTs are summarized in Table 3. The average length of follow up was 22.64 weeks with follow up ranging from 24 hours $^{11}$ and 52 weeks. ${ }^{12}$ Studies took place in hospitals; ${ }^{11-12}$, ${ }^{13}$ outpatient clinics; ${ }^{14,17-18,23}$ custodial settings; ${ }^{15,22}$ a HIV clinic; ${ }^{16}$ a drug treatment service; ${ }^{20}$ an Aboriginal health service ${ }^{19}$ and in a university setting. ${ }^{21}$

\section{Results of controlled trials}

Three RCTs reported on interventions with people who use drugs. ${ }^{12,18,20 .}$ At 12 and 26 weeks, a 36-week intervention with alcohol dependent patients in early recovery, using 16 sessions of Cognitive Behaviour Therapy (CBT) + Nicotine Replacement Therapy (NRT) was found to have a statistically significant impact on the 7-day point prevalence quit rate (both $p=.03$ ). ${ }^{12}$ However, this effect was no longer statistically significant at 38 or 52 weeks (ibid.). A study using an ENDS device ${ }^{18}$ found that the intervention was effective in reducing self-reported cigarette consumption with a biochemically verified (<8ppm CO) end of treatment smoking abstinence rate of $8.6 \%$ (intent-to-treat) and $10.7 \%$ for the per protocol group $(n=28)$. Twenty-eight percent of those who completed the program reported a $50 \%$ reduction in cigarette consumption, however, this did not seem to have been corroborated by biochemical verification (ibid.). A NRT based intervention, which included a computerised feedback component, did not increase motivation to quit or increase long term abstinence. ${ }^{20}$

Two RCTs reported mental health outcomes of interventions with people living with mental illness. One study ${ }^{11}$ investigated the effect of NRT in reducing agitation in people living with schizophrenia as measured by the Mean Agitated Scale score over a 24-hour period. The mean Agitated Behaviour Scale score for the group receiving NRT was 33\% lower at 4 hours and $23 \%$ lower at 24 hours than the placebo group (ibid.). Another study, ${ }^{13}$ also in an inpatient unit, compared the effect of patches, gum and inhalers, and found that the groups using inhalers or gum had significantly reduced psychiatric symptom severity symptoms at weeks 4 and 12 with the inhaler group showing the greatest reductions. Only the inhaler group was found to have a significant reduction in $\mathrm{CO}$ at weeks 4 and $12(\mathrm{P}<0.001$ and $\mathrm{P}=$ 0.032 , respectively) but both the nicotine inhaler and the patch groups showed significant decrease in nicotine withdrawal symptoms from baseline at both weeks 4 and 8 (ibid.).

Two studies considered NRT pre-loading (pre supplementation with nicotine) to increase treatment efficacy for people living with mental illness. ${ }^{14,17}$ One study ${ }^{14}$ which investigated the effect of NRT pre- 
loading with a $21 \mathrm{mg}$ nicotine patch found that those receiving the intervention were more likely to be abstinent (3 months $8.5 \%$ vs. $1.0 \%$, respectively, $p=.01$ ) and were more likely to accept four or more cessation sessions $(50.8 \%$ vs $29.2 \%$, respectively, $p<.001)$. However, a study ${ }^{17}$ exploring NRT pre-loading with another population of people with serious mental illness found no statistically significant reduction in smoking or craving during the preloading period and no differences in terms of 6 week or 6 -month abstinence when compared to the control group.

A 10 week group intervention with NRT with women in prison found that point prevalence quit rates for the intervention group, as compared to a waitlist control, were $18 \%$ at end of treatment, $17 \%$ at 3-month follow-up, $14 \%$ at 6 -month follow-up, and $12 \%$ at 12 - month follow-up. ${ }^{15}$ An intervention with men in prison found that Motivational Interviewing $(\mathrm{Ml})+$ NRT was more effective than Ml only in reducing smoking as biochemically validated with $\mathrm{CO}(\mathrm{p}=0.02) .^{22}$

An intervention with pregnant Indigenous women with online sessions, NRT and CO monitoring, evaluated through a step cluster design, led to biochemically validated (<6ppm) 12 week 7-day point-prevalence abstinence in $13 . \%(n=3)$ of participants. ${ }^{19}$ A study exploring the effect of NRT contacts with people living with HIV found that the number of contacts was significantly associated with 6 month abstinence. ${ }^{23}$ Another study with people living with HIV found that a 8 week NRT + counselling intervention found that the treatment group smoked less cigarettes per day $(\eta 2=.07 ; p=.13)$; had lower physical nicotine dependence $(\eta 2=.18, p=.01)$ and lower smoking urges $(\eta 2=.16, p=.01) .{ }^{16}$

A novel study ${ }^{21}$ compared two very low nicotine cigarettes with one higher nicotine cigarettes in an intervention with individuals with affective disorders, individuals with opioid use disorder and women smokers with socioeconomic disadvantage. The very low nicotine cigarettes led to reductions in cigarettes per day but there were no significant differences between the two very low nicotine cigarette types (ibid.).

\section{Quality Appraisal of Controlled Trials}

The overall quality of the controlled trials, as evaluated using the JBI Appraisal Tool, was found to be low with an average of 5.92/13 with a range from 3-9/13. Almost fifty percent of studies did not use or did not clearly describe true randomisation procedures (6/13 studies). All studies did not clearly describe concealing allocation to the treatment group (13/13 papers). Many of the studies ( $9 / 13$ studies) reported that the treatment groups were similar at baseline. Only two of the 13 studies, clearly outlined that their participants were blind to treatment assignment whilst only one study clearly outlined that those delivering treatment were blind to treatment allocation; four studies stated assessors were blind to treatment. Most studies (11/13 studies) clearly outlined that treatment groups were treated identically other than the intervention of interest. Six of the studies completed follow up or adequately explained loss to follow up. Seven of the studies analysed participants in the groups to which they were randomised. Most studies (12/13) clearly described that outcomes were measured in the same way between treatment groups. Four of the studies delineated how their measurements were performed 
reliably. Five of the studies accurately described how they had used the correct statistical techniques. Eight of the studies utilised an appropriate trial design and satisfactorily reported any deviations from the trial design.

\subsection{Uncontrolled trials}

\subsubsection{Summary of uncontrolled trials}

The results from the included uncontrolled trials are summarized in Table 3. The average length of follow up was 20 weeks, ranging from 4 weeks ${ }^{38}$ and 52 weeks. ${ }^{39}$ Studies took place in homeless services; ${ }^{25}$, $27-28,36$ drug treatment services; ${ }^{35,37,39}$ outpatient clinic; ${ }^{24,26}$ prison; $^{34}$ a gay health clinic; ${ }^{29}$ a community health clinic $^{30}$ and a veteran health clinic. $^{38}$

\section{Summary of Uncontrolled Trial Results}

An intervention with people living with HIV consisting of 5 sessions of smoking cessation counselling with NRT led to $28 \%$ biochemically verified abstinence from smoking at 6 months. ${ }^{24}$ An intervention with men who have sex with men consisting of 7 weekly sessions facilitated by peers with NRT was found to be significantly associated with point prevalence abstinence $(p=0.00)$ with $38.6 \%$ reported smoking abstinence over the previous 7 days at 6 months. ${ }^{29} \mathrm{~A}$ study which evaluated a decreasing regiment of NRT patches with people in prison was found to lead to biochemically validated point prevalence abstinence and continuous abstinence rates of $26 \%$ and $22 \%$ respectively. ${ }^{34} \mathrm{~A}$ partially student run intervention which utilised NRT with people experiencing homelessness led to $13.7 \%$ of participants contacting the smoking cessation line. ${ }^{25} \mathrm{~A}$ small scale study, using NRT patches, with people accessing mental health services found that the intervention led to a reduction in the number of daily cigarettes number of cigarettes, dependency levels and average weekly expenditure on tobacco at 3 months. ${ }^{31}$

Several studies evaluated interventions related to ENDS devices. An intervention with people experiencing homelessness using information advice, group sessions, NRT and providing a choice of ENDS device found an $18 \%$ increase in odds of reporting 7-day, biochemically verified, point-prevalence abstinence. ${ }^{27}$ All study participants reporting abstinence used an ENDS device and those using an ENDS device were found to have a $44 \%$ reduction in smoking intensity and a 1.2-point reduction in dependence (ibid.) Another study, with people experiencing homelessness and using an ENDS device, found biochemically validated sustained abstinence $3 / 48(6.25 \%)$ at 24 weeks in the treatment group compared to $0 / 32(0 \%)$ for the usual care group. ${ }^{28}$

A small ENDS intervention with people experiencing homelessness found a statistically significant decrease in reported cigarettes smoked and decrease in Fagerstrom scores $(p<0.001) .{ }^{36}$ However, decreases in biochemically validated abstinence were not statistically significant (ibid.). A six week ENDS intervention with people with serious mental illness was found to lead to a $(\geq 50 \%)$ reduction in cigarettes consumed per day between baseline and week $6(p<0.001) .{ }^{30}$ Another ENDS based intervention with 
veterans with mental health issues was found to lead to significant reductions in breath $C O(p<0.02)$ and self-reported cigarettes smoked $(p<0.001) .{ }^{38}$

A study evaluating a $21 \mathrm{mg}$ NRT patch intervention with people using drugs stated that seven subjects (14.3\%) self-reported tobacco abstinence at 21 days, and 5 (10.2\%) self-reported abstinence as outpatients at 6 weeks. ${ }^{35}$ An ENDS-based intervention, with a population recruited from a methadone clinic, was found to lead to a reduction in the number of cigarettes smoked at 3 weeks $(P<0.001), 5$ weeks $P<.001)$ and 9 weeks $(P<0.01)^{37}$.Similarly, a NRT intervention with people in a residential treatment centre reported extremely high in-treatment (85\%) and posttreatment (99\%) abstinence rates. ${ }^{39}$

Mental health and other benefits are reported by several studies. A study with people experiencing homelessness, using an ENDS device, found that GAD-7, PHQ-9 and AUDIT scores declined from baseline. ${ }^{28}$ Another study using an ENDS device with people experiencing homelessness found a decrease in "poor concentration" over the treatment period. ${ }^{36}$ An intervention using NRT and weekly peer led sessions with men who have sex with men was found to increase mental health between baseline and follow up $(p=0.00) .{ }^{29}$ However, there was no difference between depression and anxiety scores between those who had relapsed and those who did not $(p>0.05)$. A community-based study with people who use drugs found that an intervention including a NRT component led to a considerable reduction in self-reported illicit substance use (18.8\%), including a reduction in the opioids heroin (6.3\%), fentanyl (2.6\%) and Oxycontin (3.8\%). ${ }^{33}$ Other reported benefits included improved health, return to work and greater community engagement (ibid.)

\section{Quality Appraisal of Uncontrolled studies}

The overall quality of the uncontrolled trials, using the JBI Appraisal Tool, was found to be low with an average of 2.5/9 with a range from $0-6 / 9$. The cause and effect of the study was clearly articulated in most studies (11/16 studies). Only one study included a control group and there were differences between the treatment and control group. Four studies had completed follow up and/or used intention to treat analysis. Four studies included comparisons but only one clearly outlined that outcomes were measured in the same manner. No study clearly outlined that measurements were performed in a reliable way. Eight of the studies clearly outlined that they had used the appropriate statistical test.

\section{Controlled studies}




\begin{tabular}{|c|c|c|c|c|}
\hline & $\begin{array}{l}\text { Study Primary or } \\
\text { secondary aim }\end{array}$ & Smoking outcomes & $\begin{array}{l}\text { Other } \\
\text { outcomes }\end{array}$ & $\begin{array}{l}\text { Appraisal } \\
\text { score }\end{array}$ \\
\hline $\begin{array}{l}\text { Allen et al } \\
(2011)^{11}\end{array}$ & $\begin{array}{l}\text { To investigate the } \\
\text { effect of NRT in the } \\
\text { reduction of agitation } \\
\text { and aggression }\end{array}$ & Not applicable & $\begin{array}{l}\text { M1: Mean } \\
\text { Agitated } \\
\text { Behaviour } \\
\text { Scale score for } \\
\text { NRT group was } \\
33 \% \text { lower at } 4 \\
\text { hours and } 23 \% \\
\text { lower at } 24 \\
\text { hours than the } \\
\text { placebo group }\end{array}$ & $8 / 13$ \\
\hline $\begin{array}{c}\text { Carmody } \\
(2013)^{12}\end{array}$ & $\begin{array}{l}\text { To investigate the } \\
\text { efficacy of an intensive } \\
\text { tobacco cessation } \\
\text { intervention for } \\
\text { alcohol-dependent } \\
\text { smokers in early } \\
\text { recovery. }\end{array}$ & $\begin{array}{l}\text { At } 12 \text { and } 26 \text { weeks the } 7 \\
\text { day point prevalence quit } \\
\text { rates were significantly } \\
\text { higher in the intensive care } \\
\text { group (both } p=.03 \text { ). } \\
\text { However, the quit rates } \\
\text { were not statistically } \\
\text { significant at } 38 \text { or } 52 \\
\text { weeks }\end{array}$ & $\begin{array}{l}\text { Verified 30-day } \\
\text { alcohol } \\
\text { abstinence } \\
\text { were not } \\
\text { statistically } \\
\text { significant at } \\
\text { any of the } \\
\text { follow up } \\
\text { points. }\end{array}$ & $3 / 13$ \\
\hline $\begin{array}{l}\text { Chan et al., } \\
(2020)^{13}\end{array}$ & $\begin{array}{l}\text { To compare } \\
\text { effectiveness and } \\
\text { acceptability of } 3 \\
\text { different forms of NRT }\end{array}$ & $\begin{array}{l}\text { Nicotine inhaler group } \\
\text { showed statistically } \\
\text { significant reduction in co } \\
\text { level from baseline at both } \\
\text { weeks } 4 \text { and } 8 \text { ( } P<0.001 \\
\text { and } P=0.032 \text {, } \\
\text { respectively). } \\
\text { The nicotine inhaler and } \\
\text { the patch group showed } \\
\text { significant decrease in } \\
\text { nicotine withdrawal } \\
\text { symptoms from baseline } \\
\text { at both weeks } 4 \text { and } 8 \text {. }\end{array}$ & $\begin{array}{l}\text { The nicotine } \\
\text { inhaler and the } \\
\text { gum groups } \\
\text { showed } \\
\text { significant } \\
\text { decrease in } \\
\text { psychiatric } \\
\text { symptom } \\
\text { severity from } \\
\text { baseline at both } \\
\text { weeks } 4 \text { and } 8 \text {. }\end{array}$ & $8 / 13$ \\
\hline $\begin{array}{l}\text { Christiansen } \\
\text { et al. } \\
(2017)^{14}\end{array}$ & $\begin{array}{l}\text { To test a pre-cessation } \\
\text { intervention }\end{array}$ & $\begin{array}{l}\text { Smokers receiving the } \\
\text { intervention were more } \\
\text { likely to be abstinent at } 3 \\
\text { months } 8.5 \% \text { vs. } 1.0 \% \text {, } \\
\text { respectively, } \mathrm{p}=.01) \text {. } \\
\text { More likely to accept } 4 \text { or } \\
\text { more cessation sessions } \\
50.8 \% \text { vs } 29.2 \% \text {, } \\
\text { respectively, } \mathrm{p}<.001) \mathrm{b}\end{array}$ & & $7 / 13$ \\
\hline $\begin{array}{l}\text { Cropsey } \\
(2008)^{15}\end{array}$ & $\begin{array}{l}\text { To test the efficacy of } \\
\text { a combined } \\
\text { pharmacologic and } \\
\text { behavioral smoking } \\
\text { cessation intervention }\end{array}$ & $\begin{array}{l}18 \% \text { at end of } \\
\text { treatment, } 17 \% \text { at } 3 \text {-month } \\
\text { follow-up, } 14 \% \text { at } 6 \text {-month } \\
\text { follow-up, and } 12 \% \text { at } 12- \\
\text { month follow-up }\end{array}$ & & $5 / 13$ \\
\hline
\end{tabular}


$\begin{array}{ll}\begin{array}{l}\text { Cropsey } \\ (2014)^{16}\end{array} & \begin{array}{l}\text { To evaluate the } \\ \text { acceptability, }\end{array} \\ & \text { feasibility, and effects } \\ & \text { of a Screening, Brief } \\ & \text { Intervention, and } \\ & \text { Referral for Treatment } \\ & \text { (SBIRT) model i }\end{array}$
Treatment group smoked fewer cigarettes per $\operatorname{day}(\mathrm{n} 2=.07 ; \mathrm{p}=.13) ;$ had lower physical nicotine dependence $(\eta 2=.18, p=$ $.01)$; lower smoking urges (lower smoking urge ( $\mathrm{n} 2$ = $.16, p=.01$ )

$\begin{array}{ll}\text { Dennis et } & \begin{array}{l}\text { To evaluate the } \\ \text { al., (2016) }\end{array} \\ & \begin{array}{l}\text { efficacy of } \\ \text { supplemental nicotine } \\ \text { patch-preloading } \\ \text { among smokers }\end{array}\end{array}$

Felicione et

To examine the

al.,(2018) $)^{18}$

feasibility, acceptability, and effect of e-CIG on smoking behavior among smokers with opiate use disorder.
: Nicotine patchpreloading failed to reduce smoking or craving during the preloading phase

no differences were observed between the treatment conditions for time to lapse, 6-week abstinence, or 6-month abstinence.
No effect on $\quad 9 / 13$ smokingassociated relief from PTSD symptoms and negative affect.

S1: End of treatment smoking abstinence was $8.6 \%$ (intent-to-treat; $n=35$ ) and $10.7 \%$ for per protocol group $(n=28) .28 \%$ of those who completed the program were able to achieve a $50 \%$ reduction to their baseline cigarette consumption.

Gould et al., To explore the $(2019)^{19}$ feasibility and acceptability of a) a co-designed multicomponent intervention for HPs at Aboriginal Medical Services (AMSs) in culturally-targeted pregnancy-specific smoking cessation care

Higgins et al., $(2020)^{20}$
To examine whether very low-nicotinecontent (VLNC) cigarettes decrease smoking rates and dependence severity
CO validated ( $<6 \mathrm{ppm})$

Self-reported 12-week 7-

day point-prevalence

abstinence was $13.6 \%$ $(n=3)$

At week 12, mean (SEM)

CPD decreased to 17.96

(0.98) CPD

in the $0.4 \mathrm{mg} / \mathrm{g}$ group and to 19.53 (1.07) CPD in the $2.4 \mathrm{mg} / \mathrm{g}$ group, both of which were significantly

different from the 15.8 $\mathrm{mg} / \mathrm{g}$ group (25.08 [1.08] 
CPD at week 12) but not

each other $(0.4 \mathrm{mg} / \mathrm{g})$

Fagerstrom Dependence

Test Scores were

significantly different

between the very low

nicotine cigarettes and the

higher nicotine cigarettes

Hall

$(2018)^{21}$

To evaluate an

intervention to increase

cigarette abstinence

rates
S1: Did not increase long

$5 / 13$

term abstinence

D1: Increased motivation to quit

S2: Lower $\mathrm{CO}$ with $\mathrm{MI}$ with

NRT group $(p=0.02)$

$3 / 13$

Jalali et al., To compare the effects

$(2015)^{22}$

and its combination

with NRT on smoking

in prison population.

Stanton et To examine 6 month

al., $(2009)^{23}$ abstinence from

Positive PATHS trial
S1: Number of NRT contacts is sig associated with abstinence at 6 month

Total effect of NRT contacts suggested an increase in the regression adjusted odds of smoking abstinence by $35 \%$ per additional contact
D1:Sig direct effect of NRT

$4 / 13$ contacts mediators: smoking selfefficacy and smoking decisional balance.

01: The mean number of total NRT-related contacts per patient did not differ significantly between the SC and ME groups

\section{Uncontrolled}




\begin{tabular}{|c|c|c|c|c|}
\hline & $\begin{array}{l}\text { Study Primary } \\
\text { or secondary } \\
\text { aim }\end{array}$ & Smoking outcomes & $\begin{array}{l}\text { Other } \\
\text { outcomes }\end{array}$ & $\begin{array}{l}\text { Appraisal } \\
\text { score }\end{array}$ \\
\hline $\begin{array}{l}\text { Balfour } \\
(2016)^{24}\end{array}$ & $\begin{array}{l}\text { To examine the } \\
\text { effectiveness of } \\
\text { a } \\
\text { specifically } \\
\text { tailored 5- } \\
\text { session } \\
\text { smoking } \\
\text { cessation } \\
\text { counselling } \\
\text { programme }\end{array}$ & $\begin{array}{l}\text { 6-month follow-up, } 28 \% \text { of } \\
\text { participants demonstrated } \\
\text { biochemically } \\
\text { verified abstinence from smoking }\end{array}$ & $\begin{array}{l}\text { Lower } \\
\text { depression } \\
\text { than at } \\
\text { baseline but } \\
\text { statistically } \\
\text { significant } \\
(p=0.058)\end{array}$ & $3 / 9$ \\
\hline $\begin{array}{l}\text { Buckley et } \\
\text { al., (2017) }\end{array}$ & $\begin{array}{l}\text { To describe a } \\
\text { professional } \\
\text { and student run } \\
\text { program; }\end{array}$ & $\begin{array}{l}19(13.7 \%) \text { successfully contacted } \\
\text { the smoking cessation } \\
\text { quitline. }\end{array}$ & & $1 / 9$ \\
\hline $\begin{array}{l}\text { Cioe et al., } \\
(2019)^{26}\end{array}$ & $\begin{array}{l}\text { To examine the } \\
\text { acceptability } \\
\text { and health- } \\
\text { related effects } \\
\text { of ENDS }\end{array}$ & $\begin{array}{l}\text { At week } 8 \text {, cigarettes per day (CPD) } \\
\text { were reduced by more than } 80 \% \text {, } \\
\text { with reduction maintained at } \\
\text { week } 12(p \text { 's }<.001) \text {. Cigarette } \\
\text { dependence scores were } 40 \% \text { lower } \\
\text { at week } 8 \text { than at baseline }(p< \\
.001) . \text { Mean CO decreased } \\
\text { significantly } \\
\text { from BL to week } 8(p<.05) \text { and } \\
\text { remained significantly lower at } \\
\text { week } 12(p<.001)\end{array}$ & & $4 / 9$ \\
\hline $\begin{array}{l}\text { Collins et al } \\
(2019)^{27}\end{array}$ & $\begin{array}{l}\text { To explore the } \\
\text { feasibility, } \\
\text { acceptability } \\
\text { and HR QoL } \\
\text { outcomes }\end{array}$ & $\begin{array}{l}\text { Reductions in cigarette dependence } \\
(45 \%) \text {, frequency }(-29 \%) \text {, and } \\
\text { intensity }(78 \% ; \text { ps }<.05) \text {. } \\
\text { Participants who used ENDS } \\
\text { experienced an additional } 44 \% \\
\text { reduction in smoking intensity and } \\
\text { a } 1.2-\text {-point reduction in } \\
\text { dependence }\end{array}$ & $\begin{array}{l}\text { Health related } \\
\text { quality of life } \\
\text { outcomes } \\
\text { were not } \\
\text { statistically } \\
\text { significant } \\
\text { (ps }>.06) \text {. }\end{array}$ & $3 / 9$ \\
\hline
\end{tabular}




\begin{tabular}{|c|c|c|c|c|}
\hline $\begin{array}{l}\text { Dawkins } \\
(2020)^{28}\end{array}$ & $\begin{array}{l}\text { To assess the } \\
\text { feasibility of } \\
\text { supplying free } \\
\text { e-cigarette } \\
\text { starter kits to } \\
\text { smokers } \\
\text { accessing } \\
\text { homeless } \\
\text { centres and to } \\
\text { estimate } \\
\text { parameters to } \\
\text { inform a } \\
\text { possible future } \\
\text { larger trial }\end{array}$ & $\begin{array}{l}\text { CO validated sustained abstinence } \\
\text { at } 24 \text { weeks was } 3 / 48(6.25 \%) \text { and } \\
0 / 32(0 \%) \text { respectively for the EC } \\
\text { and UC arms }\end{array}$ & $\begin{array}{l}\text { GAD-7, PHQ-9 } \\
\text { and AUDIT } \\
\text { scores } \\
\text { declined from } \\
\text { baseline }\end{array}$ & $6 / 9$ \\
\hline \multirow[t]{5}{*}{$\begin{array}{l}\text { Dickson } \\
\text { Spillman } \\
(2014)^{29}\end{array}$} & $\begin{array}{l}\text { To examine if } \\
\text { the impact of } \\
\text { the intervention } \\
\text { to }\end{array}$ & $\begin{array}{l}\text { S1: Point prevalence abstinence } \\
\text { increased significantly }(p-0.00)\end{array}$ & \multirow{2}{*}{$\begin{array}{l}\text { M1: Mental } \\
\text { health } \\
\text { increased } \\
\text { between } \\
\text { baseline and } \\
\text { follow up } \\
(p=.00)\end{array}$} & \multirow[t]{5}{*}{$4 / 9$} \\
\hline & \multirow{4}{*}{$\begin{array}{l}\text { facilitate } \\
\text { smoking } \\
\text { cessation and } \\
\text { improve other } \\
\text { health } \\
\text { outcomes as } \\
\text { well as to } \\
\text { assess its } \\
\text { attractiveness } \\
\text { to the } \\
\text { target } \\
\text { population }\end{array}$} & $\begin{array}{l}\text { At } 6 \text { month } 28.6 \% \text { reported } \\
\text { smoking abstinence over the } \\
\text { previous } 7 \text { days }\end{array}$ & & \\
\hline & & & \multirow{3}{*}{$\begin{array}{l}\text { There was no } \\
\text { difference } \\
\text { between } \\
\text { depression } \\
\text { and anxiety } \\
\text { scores } \\
\text { between } \\
\text { those who } \\
\text { had relapsed } \\
\text { and those } \\
\text { who did not } \\
(p>.05) \text {. }\end{array}$} & \\
\hline & & & & \\
\hline & & & & \\
\hline $\begin{array}{l}\text { Hickling et } \\
\text { al }(2019)^{30}\end{array}$ & $\begin{array}{l}\text { To investigate } \\
\text { the utility of } \\
\text { electronic } \\
\text { cigarettes (e- } \\
\text { cigarettes) as a } \\
\text { harm reduction } \\
\text { intervention }\end{array}$ & $\begin{array}{l}\text { S1: }(\geq 50 \%) \text { reduction in cigarettes } \\
\text { consumed per day between } \\
\text { baseline and week } 6 \\
(F(2.596,116.800)=25.878, p<0.001)\end{array}$ & & $3 / 9$ \\
\hline $\begin{array}{l}\text { Johnson et } \\
\text { al., } 2020^{31}\end{array}$ & $\begin{array}{l}\text { To test a new } \\
\text { program for } \\
\text { helping } \\
\text { smokers with } \\
\text { severe mental } \\
\text { illness to reduce } \\
\text { their tobacco } \\
\text { use, together } \\
\text { with } \\
\text { determining the } \\
\text { feasibility of } \\
\text { such research } \\
\text { in community }\end{array}$ & $\begin{array}{l}\text { reduced their number of daily } \\
\text { cigarettes, dependency levels and } \\
\text { average weekly expenditure on } \\
\text { tobacco }\end{array}$ & & $1 / 9$ \\
\hline
\end{tabular}


mental health

settings

Mikhailovich

and

Morrison

$(2008)^{32}$

Pakhale 33
To valuate a

NRT tailored

program
Mean reduction of 11.2 cigarettes at 6 months $(P=0.0001)$. the feasibility of

a Community

Based

Participatory

Tobacco

Dependence

Strategy considerable

reduction in

self-reported

illicit

substance

use (18.8\%),

including a

reduction in

the opioids

heroin (6.3\%),

fentanyl

(2.6\%) and

Oxycontin

(3.8\%).

Other

reported

benefits

included

improved

health, return

to work and

greater

community

engagement
Richmond et al., (2006) $)^{34}$

Saxon,

McGuffin and Walker, $(1997)^{35}$
To determine the feasibility and

effectiveness of

a multi-

component

smoking

cessation biochemically validated point prevalence

and continuous abstinence rates

were $26 \%$ and $22 \%$ respectively
To undertake an

open, pilot

evaluation of

transdermal

nicotine for

cigarette

smokers
Seven subjects (14.3\%) self-

reported tobacco

abstinence at 21 days, and 5

$(10.2 \%)$ self-reported abstinence as

outpatients at 6 weeks 


\begin{tabular}{|c|c|c|c|}
\hline \multirow[t]{3}{*}{ al., $(2020)^{36}$} & \multirow{3}{*}{$\begin{array}{l}\text { efficacy, } \\
\text { challenges and } \\
\text { opportunities of } \\
\text { using electronic } \\
\text { nicotine delivery } \\
\text { systems } \\
\text { (ENDS) to } \\
\text { support } \\
\text { cessation of } \\
\text { tobacco } \\
\text { smoking }\end{array}$} & \multicolumn{2}{|l|}{$\begin{array}{l}\text { consumption were found to be } \\
\text { statistically significant }(p<0.001)\end{array}$} \\
\hline & & \multicolumn{2}{|l|}{$\begin{array}{l}\text { Reductions in carbon monoxide } \\
\text { measurements were not } \\
\text { statistically significant. }\end{array}$} \\
\hline & & \multicolumn{2}{|l|}{$\begin{array}{l}\text { Decreases in Fagerström Nicotine } \\
\text { Dependence Test were statistically } \\
\text { significant (p =0.001), but } \\
\text { decreases in MPSS "urge to } \\
\text { smoke" and "strength of urges" } \\
\text { composite scores were not. }\end{array}$} \\
\hline $\begin{array}{l}\text { Stein et al., } \\
(2016)^{37}\end{array}$ & $\begin{array}{l}\text { To conduct a } \\
\text { small open pilot } \\
\text { trial on the use } \\
\text { of e-cigarettes } \\
\text { as a smoking } \\
\text { cessation }\end{array}$ & $\begin{array}{l}\text { S1: Mean reductions in CPD were } \\
-12.4(95 \% \text { confidence interval [Cl]: } \\
-15.0,-9.9 ; \mathrm{P}<.001),-14.8(95 \% \\
\mathrm{Cl}:-17.4,-12.2 ; \mathrm{P}<.001),-13.9 \\
(95 \% \mathrm{Cl}:-16.6,-11.2), \text { and }-10.8 \\
(95 \% \mathrm{Cl}:-13.4,-8.2 ; \mathrm{P}<.01) \text { at the } \\
3-, 5-, 7-\text {, and } 9 \text {-week assessments, } \\
\text { respectively. }\end{array}$ & $3 / 9$ \\
\hline $\begin{array}{l}\text { Valentine } \\
2018^{38}\end{array}$ & $\begin{array}{l}\text { To examine the } \\
\text { impact of e- } \\
\text { cigarette use on } \\
\text { combustible } \\
\text { tobacco use, as } \\
\text { well as on the } \\
\text { readiness to } \\
\text { quit smoking } \\
\text { and changes in } \\
\text { nicotine } \\
\text { dependence }\end{array}$ & $\begin{array}{l}\text { Significant reductions in breath CO } \\
(9.3 \mathrm{ppm} \text { to } 7.3 \mathrm{ppm}, \mathrm{p}<0.02 \text { ) and } \\
\text { CPD (from } 16.6 \text { to } 5.7, \mathrm{p}<0.001\end{array}$ & $2 / 9$ \\
\hline White & To explores the & High in-treatment (85\%) & $1 / 9$ \\
\hline$(2016)^{\circ}$ & $\begin{array}{l}\text { a smoking } \\
\text { cessation } \\
\text { intervention }\end{array}$ & $\begin{array}{l}\text { and posttreatment }(99 \%) \\
\text { abstinence rates }\end{array}$ & \\
\hline
\end{tabular}

\section{Discussion}

There is limited evidence that many NRTs (for example, gum, patches and inhalers) and ENDS based interventions have a positive effect on self-reported smoking with the marginalised groups focused upon in this review. Evidence that does exist is often not corroborated with biochemical validation. Clear standards for $\mathrm{CO}$ cut off points for biochemical validation seem to be lacking with studies using cut-offs as low as $4 \mathrm{ppm} \mathrm{CO}$ and as high as 10ppm CO and various different devices. Additionally, the evidence for these interventions is negatively impacted by the poor design of many of the reviewed trials.

Overall, the methodological quality of the studies was very poor with an average score of $5.92 / 13$ in the RCT group and an average score of 2.5/9 in the quasi-experimental group. Few studies were identified where outcomes were measured in a reliable manner. 
It was difficult to ensure that statistical analysis was appropriate using the JBI checklist, due to a dearth of information given in the majority of studies. None of the controlled trials and only one uncontrolled trial $^{37}$ identified that they carried out statistical power analysis; therefore the assumption that other studies were underpowered could not be dismissed. The studies did not use power analysis to determine the effect size of different forms of NRT or ENDS or complementary psychological interventions as part of the treatment arms. Studying the reliability of ANDs intervention statistics was therefore a complex task and using more robust methods such as intention to treat in larger and statistically powered trials would improve future studies and thereby enable comparison of outcomes. The importance of the studies included in determining the feasibility and effects of ANDs in minority groups cannot be dismissed.

Preliminary evidence suggests that engagement with smoking related interventions may have a positive effect on mental health $11,13,24,28-29,36$ though this is not reported in all trials ${ }^{17}$. This may not be related to meeting smoking abstinence outcomes ${ }^{29}$ although there is consistent evidence that smoking cessation is associated with mental health benefits. ${ }^{40}$ There may also be benefits in relation to substance use, general health and employment. ${ }^{33}$

Although there were several ENDS-based interventions found in the quasi-experimental studies $26-28,30$, 36-37 only one included $\mathrm{RCT}^{18}$ evaluated this type of intervention. In the context of potential benefits for smoking reduction ${ }^{41}$ and the ongoing debates ${ }^{42-43}$ around the potential benefits and harms of these interventions, further study in properly powered and randomised clinical trials is warranted. Such research should evaluate the benefits and risks of such interventions in comparison to available smoking reduction options for specific groups.

This review is significantly limited due to heterogeneity regarding study type, intervention type and populations. This prevents the possibility of generalising any results. Although several quasiexperimental studies investigated interventions with people experiencing homelessness, no randomised controlled trials were identified.

Despite the fact that smoking remains extremely high in many marginalised groups, ${ }^{1,2}$ there is a relative absence of properly controlled trials with these groups. In this context it is important to note that this review included no studies of members of the Traveller, sex worker or migrant communities. This highlights a significant gap in the research literature that should be addressed in the future.

\section{Conclusion}

Future studies should aim to adopt best practice standards in relation to CO measurement as the large variance in cut off points reduces the possibility of comparing study outcomes. Several studies suggest potential mental health benefits arising from participation in smoking reduction- related interventions; such benefits should be explored in properly controlled trials. There is a current lack of RCTs related to smoking related interventions with people experiencing homelessness. Similarly, there is a lack of 
properly controlled RCTs exploring the use of ENDS with marginalised populations. Future studies should aim to address these deficits.

\section{Declarations}

\section{Ethics approval and consent to participate}

N/A

\section{Consent for publication}

N/A

\section{Availability of data and materials}

Quality Appraisal and Statistical appraisal files are available.

\section{Competing interests}

One of the reviewed studies was co-authored by FS, JW, KM and AM. No conflict of interest from AJ

\section{Funding}

This research received funding from the Knowledge Action Change Tobacco Harm Reduction Scholarship.

\section{Authors' contributions}

FS, EM, JW, KM and AM developed the protocol for this study. FS completed the literature search. FS, AJ, $\mathrm{EM}$ and FS screened the papers. AJ, EM, FS and MG completed the quality control. All authors reviewed the final version of the paper

\section{References}

1. WHO global report on trends in prevalence of tobacco smoking 2000-2025, edition. Geneva: World Health Organization; 2019.

2. Loring B. Tobacco and inequities Guidance for addressing inequities in tobacco-related harm. World Health Organisations. 2014.

https://www.euro.who.int/_data/assets/pdf_file/0005/247640/tobacco-090514.pdf. Accessed 20 Oct 2021.

3. Marmot M. Inclusion health: addressing the causes of the causes. The Lancet.2020;391(10117):186-188.

4. Vijayaraghavan $\mathrm{M}$, Elser $\mathrm{H}$, Frazer $\mathrm{K}$, Lindson $\mathrm{N}$, Apollonio D. Interventions to reduce tobacco use in people experiencing homelessness. Cochrane Database of Systematic Reviews. 2020: 12, 
CD013413. Art. No.: CD013413. DOI: 10.1002/14651858.CD013413.pub2.

5. Hayhurst K, P, Jones A, Cairns D, Jahr S, Williams E, Eastwood B, Millar T: Tobacco Smoking Rates in a National Cohort of People with Substance Use Disorder Receiving Treatment. Eur Addict Res 2021;27:151-155. doi: 10.1159/000508869

6. Cooper J, Mancuso SG, Borland R, Slade T, Galletly C, Castle D. Tobacco smoking among people living with a psychotic illness: The second Australian survey of psychosis. Australian \& New Zealand Journal of Psychiatry. 2012;46(9):851-863. doi:10.1177/0004867412449876

7. Ritter C, Stöver H, Levy M, et al. Smoking in prisons: The need for effective and acceptable interventions. J Public Health Pol. 2011: 32, 32-45. https://doi.org/10.1057/jphp.2010.47

8. Glover M, Patwardhan P, Selket K. Tobacco smoking in three "left behind" subgroups: indigenous, the rainbow community and people with mental health conditions", Drugs and Alcohol Today. 2020: 20(3): 263-281. https://doi.org/10.1108/DAT-02-2020-0004

9. Moher D, Liberati A, Tetzlaff J, Altman D G. Preferred reporting items for systematic reviews and meta-analyses: the PRISMA statement BMJ 2009; 339:b2535 doi:10.1136/bmj.b2535

10. Tufanaru C, Munn Z, Aromataris E, Campbell J, Hopp L. Systematic reviews of effectiveness. Joanna Briggs Institute reviewer's manual 3, 2017.

11. Allen MH, Debanné M, Lazignac C, Adam E, Dickinson LM, Damsa C. (2011). Effect of Nicotine Replacement Therapy on Agitation in Smokers With Schizophrenia: A Double-Blind, Randomized, Placebo-Controlled Study. American Journal of Psychiatry, 168(4), 395-399. doi:10.1176/appi.ajp.2010.10040569

12. Carmody TP, Delucchi $\mathrm{K}$, Duncan $\mathrm{CL}$, et al. Intensive intervention for alcohol-dependent smokers in early recovery: a randomized trial. Drug Alcohol Depend. 2012;122(3):186-194. doi:10.1016/j.drugalcdep.2011.09.026

13. Chan H-Y, Chen J-J, Pan Y-J, \& Hsu, C-C (2020). Nicotine Replacement Therapy and Healthy Lifestyle Psychoeducation for Smoking Reduction in Acute Psychiatric Inpatients. Journal of Clinical Psychopharmacology, 40(2), 149-156. doi:10.1097/jcp.0000000000001170

14. Christiansen B.A, Carbin J, TerBeek E, Fiore M.C. (2017). Helping Smokers with Severe Mental Illness Who Do Not Want to Quit. Substance Use \& Misuse, 53(6), 949-962. doi:10.1080/10826084.2017.1385635

15. Cropsey K, Eldridge G, Weaver M, Villalobos G, Stitzer M, Best A. (2008). Smoking Cessation Intervention for Female Prisoners: Addressing an Urgent Public Health Need. American journal of public health. 98. 1894-901. 10.2105/AJPH.2007.128207.

16. Cropsey KL, Hendricks PS, Jardin B, Clark CB, Katiyar N, Willig J, Carpenter M.J. (2013). A pilot study of Screening, Brief Intervention, and Referral for Treatment (SBIRT) in non-treatment seeking smokers with HIV. Addictive Behaviors, 38(10), 2541-2546. doi:10.1016/j.addbeh.2013.05.003

17. Dennis PA, Kimbrel NA, Dedert EA, Beckham JC, Dennis MF, Calhoun PS. (2016). Supplemental nicotine preloading for smoking cessation in posttraumatic stress disorder: Results from a randomized controlled trial. Addictive Behaviors, 59, 24-29. doi:10.1016/j.addbeh.2016.03.004 
18. Felicione NJ, Enlow P, Elswick D, Long D, Sullivan C.R., Blank MD. A pilot investigation of the effect of electronic cigarettes on smoking behavior among opioid-dependent smokers. Addictive Behaviors. 2019: 9: 45-50,ISSN 0306-4603, https://doi.org/10.1016/j.addbeh.2018.07.003.

19. Gould GS, Bovill M, Pollock L, Bonevski B, Gruppetta M, Atkins L, Carson-Chahhoud K, Boydell KM, Gribbin GR, Oldmeadow C, Hall A, Bar-Zeev Y. Feasibility and acceptability of Indigenous Counselling and Nicotine (ICAN) QUIT in Pregnancy multicomponent implementation intervention and study design for Australian Indigenous pregnant women: A pilot cluster randomised step-wedge trial,Addictive Behaviors,Volume 90,2019,Pages 176-190,ISSN 0306-4603, https://doi.org/10.1016/j.addbeh.2018.10.036.

20. Hall SM, Humfleet GL, Gasper JJ, Delucchi KL, Hersh DF, Guydish, JR. (2018). Cigarette Smoking Cessation Intervention for Buprenorphine Treatment Patients. Nicotine \& tobacco research: official journal of the Society for Research on Nicotine and Tobacco, 20(5), 628-635.

https://doi.org/10.1093/ntr/ntx113

21. Higgins ST, Tidey JW, Sigmon SC, et al. Changes in Cigarette Consumption With Reduced Nicotine Content Cigarettes Among Smokers With Psychiatric Conditions or Socioeconomic Disadvantage: 3 Randomized Clinical Trials. JAMA Netw Open. 2020;3(10):e2019311.

doi:10.1001/jamanetworkopen.2020.19311

22. Jalali F, Afshari R, Babaei A, Abasspour H, Vahedian-Shahroodi M. (2015). Comparing Motivational Interviewing-Based Treatment and its combination with Nicotine Replacement Therapy on smoking cessation in prisoners: a randomized controlled clinical trial. Electronic physician, 7(6), 1318-1324. https://doi.org/10.14661/1318

23. Stanton CA, Lloyd-Richardson EE, Papandonatos GD, de Dios MA, Niaura R. (2009). Mediators of the Relationship Between Nicotine Replacement Therapy and Smoking Abstinence Among People Living With HIV/AIDS. AIDS Education and Prevention, 21(3_supplement), 65-80.

doi:10.1521/aeap.2009.21.3supp.65

24. Balfour L, Wiebe SA, Cameron WD, Sandre D, Pipe A, Cooper C, MacPherson PA. (2016). An HIVtailored quit-smoking counselling pilot intervention targeting depressive symptoms plus Nicotine Replacement Therapy. AIDS Care, 29(1), 24-31. doi:10.1080/09540121.2016.1201195

25. Buckley K, et al. A health sciences student-run smoking cessation clinic experience within a homeless population Journal of the American Pharmacists Association, Volume 57, Issue 1, 109 115.e3

26. Cioe PA, Mercurio AN, Lechner W, Costantino CC, Tidey JW, Eissenberg T, Kahler CW. (2019). A pilot study to examine the acceptability and health effects of electronic cigarettes in HIV-positive smokers. Drug and Alcohol Dependence, 107678. doi:10.1016/j.drugalcdep.2019.107

27. Collins SE, Nelson LA, Stanton J, Mayberry N, Ubay T, ... Taylor EM. (2019). Harm reduction treatment for smoking (HaRT-S): findings from a single-arm pilot study with smokers experiencing chronic homelessness. Substance Abuse, 1-11. doi:10.1080/08897077.2019.1572049 
28. Dawkins L, Bauld L, Ford A, Robson D, Hajek P, et al. (2020) A cluster feasibility trial to explore the uptake and use of e-cigarettes versus usual care offered to smokers attending homeless centres in Great Britain. PLOS ONE 15(10): e0240968. https://doi.org/10.1371/journal.pone.0240968

29. Dickson-Spillmann M, Sullivan R, Zahno B, Schaub MP. (2014). Queer quit: a pilot study of a smoking cessation programme tailored to gay men. BMC Public Health, 14(1). doi:10.1186/1471-2458-14-12

30. Hickling L, Perez-Iglesias R, McNeill A, Dawkins L, Moxham J, Ruffell T, Sendt K-V, McGuire P. (2018). A pre-post pilot study of electronic cigarettes to reduce smoking in people with severe mental illness. Psychological Medicine. 49. 10.1017/S0033291718001782.

31. Johnson SE, Mitrou F, Lawrence D, Zubrick SR, Wolstencroft K, et al., (2020). Feasibility of a Consumer Centred Tobacco Management intervention in Community Mental Health Services in Australia. Community Mental Health Journal, 56(7), 1354-1365. doi:10.1007/s10597-020-00573-z Mikhailovich K, \& Morrison P. (2008). An Evaluation of a Smoking Cessation Program for Special Populations in Australia. Journal of Smoking Cessation, 3(01), 50-56. doi:10.1375/jsc.3.1.50

32. Pakhale S, Kaur T, Charron C, Florence K, Rose T, Jama S, Tyndall M. (2018). Management and Pointof-Care for Tobacco Dependence (PROMPT): a feasibility mixed methods community-based participatory action research project in Ottawa, Canada. BMJ Open, 8(1), e018416. doi:10.1136/bmjopen-2017-018416

33. Richmond R, Indig D, Butler T, Wilhelm K, Archer V, Wodak A. (2012). A Randomised Controlled Trial of a Smoking Cessation Intervention Conducted among Prisoners. Addiction (Abingdon, England). 108. 10.1111/add.12084.

34. Saxon AJ, McGuffin R, Walker, R. (1997). An open trial of transdermal nicotine replacement therapy for smoking cessation among alcohol- and drug-dependent inpatients. Journal of Substance Abuse Treatment, 14(4), 333-337. doi:10.1016/s0740-5472(97)00031-7

35. Scheibein F, McGirr K, Morrison A, Roche W, Wells JSG. An exploratory non-randomized study of a 3month electronic nicotine delivery system (ENDS) intervention with people accessing a homeless supported temporary accommodation service (STA) in Ireland. Harm Reduct J 17, 73 (2020). https://doi.org/10.1186/s12954-020-00406-y

36. Stein MD, Caviness C, Grimone K, Audet D, Anderson BJ, Bailey GL. (2016). An Open Trial of Electronic Cigarettes for Smoking Cessation Among Methadone-Maintained Smokers. Nicotine \& tobacco research: official journal of the Society for Research on Nicotine and Tobacco, 18(5), 11571162. https://doi.org/10.1093/ntr/ntv267

37. Valentine GW, Hefner K, Jatlow PI, Rosenheck RA, Gueorguieva R, Sofuoglu M. Impact of E-cigarettes on Smoking and Related Outcomes in Veteran Smokers With Psychiatric Comorbidity. J Dual Diagn. 2018;14(1):2-13. doi:10.1080/15504263.2017.1384877

38. White WL, Daneshmand R, Funk R, Dezhakam H. (2016). A Pilot Study of Smoking Cessation within an Iranian Addiction Recovery Community. Alcoholism Treatment Quarterly, 34(1), 15-29. doi:10.1080/07347324.2016.1113108 
39. 5 ASH 'The Stolen Years - The Mental Health \& Smoking Action Report'.ASH 2016:7. ISBN 978-1872428-99-4.

40. McRobbie H, Bullen C, Hartmann-Boyce J, Hajek P. Electronic cigarettes for smoking cessation and reduction. Cochrane Database of Systematic Reviews 2014, Issue 12. Art. No.: CD010216. DOI: 10.1002/14651858.CD010216.pub2. Accessed 17 October 2021.

41. Bates CD. POINT: e-Cigarette Use for Harm Reduction in Tobacco Use Disorder? Yes. Chest, 160(3), 807-809. doi:10.1016/j.chest.2021.04.046

42. Kathuria H, Leone FT. COUNTERPOINT: e-Cigarette Use for Harm Reduction in Tobacco Use Disorder? No. Chest, 160(3), 809-811. doi:10.1016/j.chest.2021.04.044

\section{Appendix}

Appendix 1 is not available with this version.

\section{Figures}




\section{Identification of studies via databases and registers}

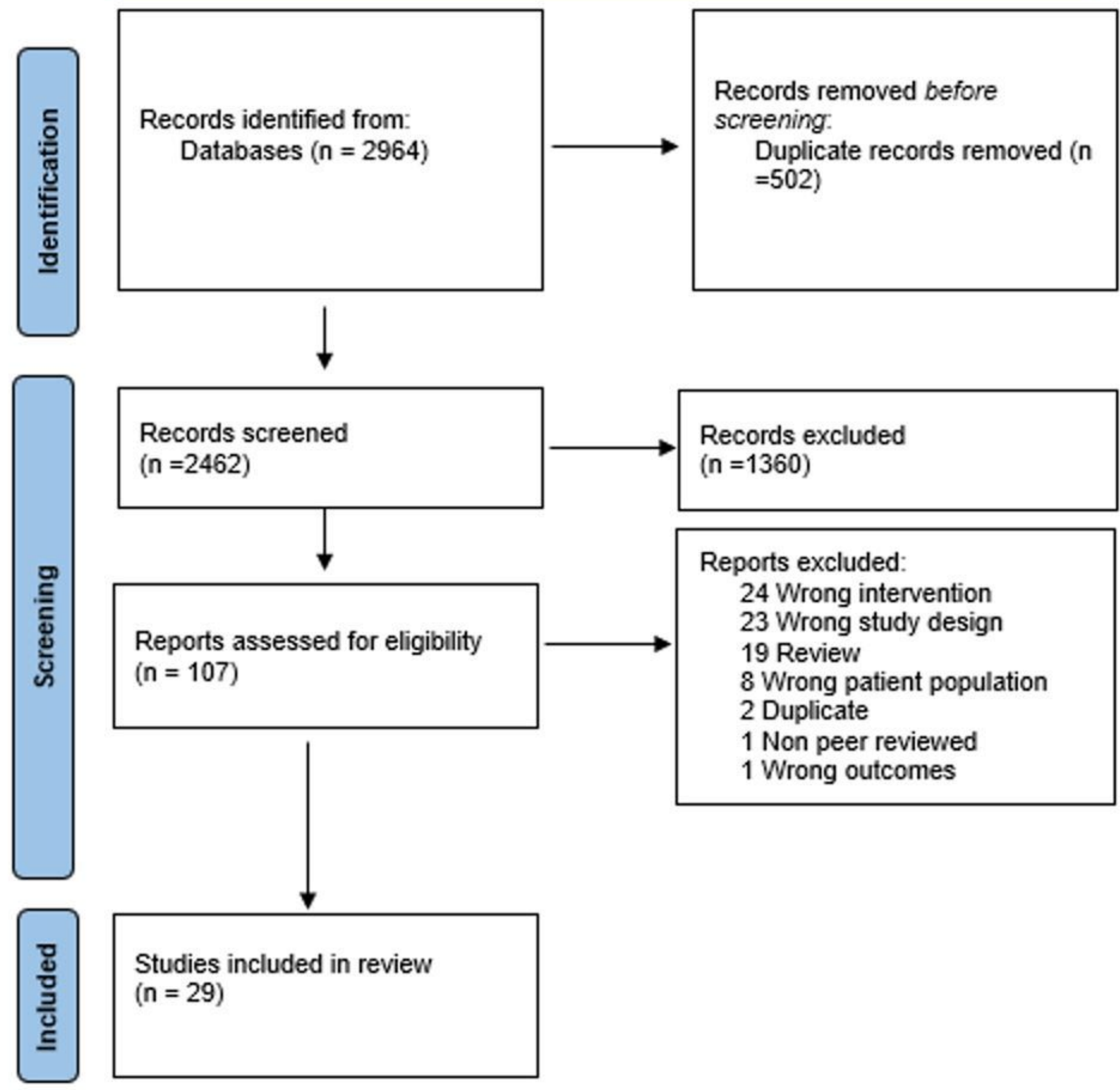

Figure 1

PRISMA Flow Chart 